\title{
Electricity Consumption and Economic Growth Nexus: Evidence from Maki Cointegration
}

\author{
Festus Victor Bekun ${ }^{1}$, Mary Oluwatoyin Agboola ${ }^{2}$
}

${ }^{1}$ Eastern Mediterranean University

Northern Cyprus, via Mersin 10, Turkey

E-mail.festus.bekun@emu.edu.tr

${ }^{2}$ College of Business Dar Al Uloom University

1 Mizan st. Al Falah, Riyadh 13314 Saudi Arabia

E-mail.maryagboola@dau.edu.sa

cross $^{\text {ref }}$ http://dx.doi.org/10.5755/j01.ee.30.1.20748

The current study revisits the dynamic relationship between electricity consumption, real gross domestic product per capita and carbon dioxide emissions in Nigeria. To do this, we adopt the Zivot-Andrews (1992) unit root test to ascertain the stationarity properties of the interest variables. Maki (2012) cointegration test which accounts for multiple structural breaks is used for long-run equilibrium relationship between the variables while the long run regressions of dynamic ordinary least square (DOLS) and fully modified ordinary least square (FMOLS) for long-run coefficients as estimation techniques. The direction of causality is detected via the Toda-Yamamoto (1995) causality test for annual time series data from 1971-2014. Empirical evidence shows there exists a long-run equilibrium relationship between electricity consumption, real gross domestic product per capita and carbon dioxide emissions. The long-run regression suggests statistical significant and positive relationship between economic growth and electricity consumption. Thus, validating the electricity-induced growth hypothesis for Nigeria. According to the Toda-Yamamoto (1995) causality test, one-way causality is observed from electricity consumption to economic growth. This is in line with apriori expectation. However, there is an environmental implication of our study findings as electricity consumption spur increases carbon dioxide emissions. It is on the above premise that the study calls for diversification of Nigeria's energy portfolio to cleaner/environmental friendly sources like renewables.

Keywords: Electricity Consumption; Economic Growth; Maki Cointegration; Dynamic Causality; Nigeria.

\section{Introduction}

In recent times, the world has experienced energy shortage. This phenomenon is due to the abrupt increase in global energy demand (Sekantsi \& Okot, 2016; Tamba et al., 2017). This is because of the pivotal role energy (electricity) consumption plays in the stimulation of socioeconomic and economic activities of both developed and developing economies. The debate is still heated in the energy economics literature as to whether economic growth precedes energy consumption or vice versa. However, much has been documented in the energy economic literature for decades, mostly in developed economies. Little is known about this very interesting dynamic interaction in developing economies, more precisely in Sub-Saharan Africa (SSA). Thus, this current study focuses on Nigeria, which is faced with a huge and alarming electricity deficit. Recent statistics for the case of Nigeria reveal that an overwhelming $95,500,000$ inhabitants of the population are without electrification, with 55 per cent of the total population without access to electricity while 45 per cent reside in urban centres and 63 per cent in rural areas (CIA, 2018). Given this backdrop, the country relies on load shedding to meet its electricity demand. Further, statistics shows that electricity consumption rose from 13.72 billion Kwh in 2000 to 24.57 billion KWh in 2018 (CIA, 2018).
The persistent increase in electricity demand for economic activities in Nigeria, a fast-growing economy in West Africa, has become more severe and threatens to become more intense in the near future if prompt attention is not given to its energy sector. This highlighted electricity issue has drawn the attention of all stakeholders, ranging from energy economist, practitioners to government administrators, to mitigate these odds for increased economic growth. Thus, this study seeks to explore the nexus between electricity consumption and economic growth given its urgency and relevance to policymakers and government administrators.

This phenomenon has inherent policy implications. Thus, this current study seeks to fill this identified gap. It is against the above-mentioned backdrops that this current study seeks to bridge the identified gap for the case of Nigeria. This study contributes to the literature in the following ways: (i) in terms of its scope by including carbon dioxide emissions to our econometrics framework; our econometrics framework is trivariate rather than bivariate, which is argued to be flawed with omitted variables (model misspecification), bias and a violation of the axioms of classical linear regression which previous studies investigated (Shahbaz \& Feridun, 2012; Tamba et al., 2017); (ii) in terms of methodological innovation because it leverages on structural break methodology given 
the nature of most macroeconomic/financial data, which previous studies fail to address.

For stationarity properties and asymptotic traits of series, this study uses the Zivot- Andrews (1992) unit root test, which accounts for a single structural break. For cointegration, the Maki (2012) cointegration test is used, which accounts for five structural breaks. Finally, for causal interaction, the Toda- Yamamoto (1995), which is a modified version of the Wald test (MWALD) for causality, is adopted, which is known to be more robust than the conventional Granger causality test. These structural break models were informed to avoid spurious analysis given breaks and jumps in the variables considered.

\section{Literature Review}

The debate is still heated in the energy economics literature as to whether economic growth precedes energy consumption or vice versa. This discussion was first introduced to the energy economics literature by the seminal studies of Kraft and Kraft (1978), where they investigated the causal nexus between energy consumption and economic growth for the United States. The study of Kraft and Kraft was an investigation of numerous studies (Akadiri \& Akadiri, 2018; Akadiri et al., 2018; Emir \& Bekun, 2018; Balcilar et al., 2010; Damette \& Seghir, 2013; Narayan \& Smyth, 2008). However, the literature can be classified into four strands, namely: those that claim that energy consumption drives economic growth (Damette \& Seghir, 2013; Ghali \& El-sakk, 2004); those that asserts that economic activities translate into higher electricity consumption, what is called in the literature conservative hypotheses (Baranzini et al., 2013; Jamil \& Ahmad, 2010); the third group (Lee et al.,2008; Tang \& Tan, 2013) is called the feedback hypothesis in the literature in which there exists a bi-directional causal relationship seen from both energy consumption and economic growth; and finally the fourth group (Halicioglu, 2009; Soytas \& Sari, 2006) is known as the neutrality hypothesis where there is no causal interaction between energy consumption and economic growth.

More recently, several other studies are evident in the energy economic literature with diverse empirical outcomes. These discrepancies in the empirics could be attributed to the study area examined sampling and data collection procedures. More importantly, methodological and estimation techniques adopted. For single-country studies (see Wang et al., 2017; Shahbaz et al., 2017; Ameyaw et al., 2016; Hamdi et al., 2014; Aslan, 2014; Belaid \& Abderrahmani, 2013). Hamdi et al. (2014) explored the nexus between electricity consumption and economic growth for the case of the Kingdom of Bahrain while accounting for capital and foreign direct investment with the aid of Cobb-Douglas production function. Their estimations reveal cointegration (equilibrium) relationship between the variables. Hamdi et al., (2014) study shows feedback causality between electricity consumption and economic growth. This position is also resonated in the empirical studies of (Aslan, 2014), for the case of Turkey. For the case of Ghana, using Cobb-Douglas growth production function is used to investigate the theme under review. Ameyaw et al. (2017) study give credence to the growth-led energy hypothesis. Thus, revealing that the Ghanaian economy is not energy-dependent. In China Wang et al. (2017), explore the nexus between economic growth and electricity consumption via a bootstrap causality approach, seemingly unrelated regression approach. Their empirical findings lend support to the economic growth induced electricity consumption. On the contrary, In Portugal Shahbaz et al. (2017) conducted a study and shows that the Portuguese economy is energydependent as unidirectional Granger causality is seen running from electricity consumption to economic growth. Their study also accounted for capital formation and financial development. More interestingly, for Turkey Nazlioglu et al. (2014), examined the theme under consideration via linear and non-linear estimators. Their study linear Granger causality supports the feedback causality in both the short and long run between electricity consumption and economic growth for Turkey. After filtering for non-linearity via the BDS non-linearity test. The nonlinear Granger causality test supports the neutrality hypothesis between the variables. Thus implying that Turkey can apply the conservative energy policy.

The other strands of studies conducted are a panel of countries. For instance the studies of Balsalobre-Lorente $e t$ al. (2018) for EU-5 countries namely (Germany, France, Italy, Spain and the United Kingdom). BalsalobreLorente's study adopted the carbon emission production function to examine the theme for the aforementioned blocs. Their empirical study reveals renewable electricity consumption improve environmental quality while the study also controlled for trade openness, natural abundance, energy innovation and carbon dioxide emission. Kahouli (2018), examined Mediterranean countries (MC's) for the nexus between electricity consumption and economic growth while controlling for carbon dioxide emissions and research development with the GMM, 3SLS and SUR econometrics methodology. Kahouli (2018) study lend supports to the electricityinduced growth. In the case of transition countries using bootstrap panel Granger causality test that accommodates for cross-sectional dependence and heterogeneity in the blocs investigated as conducted by Wold-Rufae (2014). The study found mixed results among the countries and offered requisites policy direction to the different countries. In a similar study carried out by Salahuddin (2015) examined the long-short run relationship between the theme under review for Gulf cooperation countries (GCC). The study submits to the robust relationship between the variables as well as establish the electricityled growth hypothesis for the GCC over the period investigated.

\section{Nigeria Energy Sector: A Brief}

Nigeria is one of the largest economies on the subSaharan African (SSA) continent. Nigeria's economy is topmost in oil production on the continent, followed by Angola. Nigeria holds high reserves of liquefied natural gas (LNG), also the country strives on oil production as the main source of foreign exchange earnings and revenue for the government (Wada, 2017a). Recent statistics from the US Energy Intelligence Agency (EIA, 2016) reveals that 
Nigeria's economy relies heavily on her energy sector as a source of foreign exchange earnings, as, in 2014 the oil and gas sector accounted for 95 per cent of her gross exports to the rest of the world. However, in the global plunge in the oil price market, the country lost an alarming sum of 35 billion USD of her revenue. The explanation to this outcome also accounts for the unrest in the Niger Delta region of the country from where the oil is extracted. The Niger Delta region is also characterised by theft activities of gas pipeline networks installations and infrastructures by vandals. Also identified is poor management and corruption among government officials which has crippled the energy sector with a huge loss beyond the global oil price crash.

In recent times, the Nigeria energy sector has undergone a transformation and taken strides with the privatisation of the energy sector from the National Electricity Power Authority (NEPA) to the Power Holding Company of Nigeria (PHCH). More recent facts reveal that energy demand rose in Nigeria from 13.72 billion Kwh in 2000 to 24.57 billion Kwh in 2018 (CIA, 2018); this is due to the global energy demand and Nigeria is no exception. ${ }^{1}$ Furthermore, the Nigerian government seeks to produce over 2000MW of energy from renewable energy sources which are known to be cleaner and environmentally friendly (NESP, 2015); the renewable alternatives will be from photovoltaic sources, wind and biomass. This milestone is projected to be the single largest in the world by 2030, accounting for more than half of total world output in 2040

The rest of this paper proceeds with Section 4, which presents the data and econometrics procedure while Section 5 focuses on empirical results and discussions. Finally, conclusion and policy implications form Section 6.

\section{Data and Methodological Framework}

Using annual data from 1971-2014 to explore the interaction between the electricity growth nexus for the case of Nigeria with data obtained from the CD- ROM of the World Development Indicator (WDI, 2018), ${ }^{2}$ this study empirically follows Kayhan et al. (2010) and Wada (2017b) for empirical backing. Economic growth is proxy as real gross domestic product per capita constant 2010 USD (PGDP), carbon dioxide emission $\left(\mathrm{CO}_{2}\right)$ in $\mathrm{Kt}$ as indicator for environmental degradation and electricity consumption (EC) in $\mathrm{kWh}$ per capita

\section{Model Specification}

The functional relationship between electricity consumption, carbon dioxide emissions and economic growth can be presented as follows:

$$
E L E=f\left(P G D P, C O_{2}\right)
$$

\footnotetext{
${ }^{1}$ For readers interested in the energy consumption demand chart, see the CIA web link below: https://www.indexmundi.com/g/g.aspx?c=ni\&v=81 ${ }^{2}$ The data available for $\mathrm{CO}_{2}$ and electricity were available till 2014, while RGDP was available till 2017, but the data choice of 1971-2014 was to ensure balance in the data set and to ease estimation
}

To achieve homoscedasticity, logarithm transformation is carried out in equation 1

$$
\operatorname{LnELE}=\alpha+\beta_{1} \operatorname{LnPGDP}+\beta_{2} \operatorname{LnCO}_{2}+\varepsilon_{t}
$$

Here, $\alpha$ signifies constant and $\beta_{1} \beta_{2}$ are partial slope parameter. Also, LnELE, Ln PGDP and $\mathrm{LnCO}_{2}$ are the natural logarithms for real gross domestic product per capita (PGDP), electricity consumption (ELE) and carbon dioxide emissions $\left(\mathrm{CO}_{2}\right)$.

\section{Stationarity Test}

In time series econometrics analysis, the need for stationarity test is essential to avoid spurious analysis. The econometrics literature houses numerous unit root and stationarity tests, among which are Augmented DickeyFuller (ADF) (1981) Phillips \& Perron (PP) (1988). However, most of the well-known tests do not capture for structural breaks. Given the nature of most macroeconomics/finance data, it is possible to claim that analysis made on such dataset is spurious if structural break(s) is not accounted for. It is on this premise that the current study adopts the relatively new Zivot and Andrews (1992) unit root test that ameliorates for the mentioned shortcoming. The Zivot and Andrews (ZA, hereafter) accounts for single structural break with null hypothesis of unit root (non-stationary) against an alternative of Stationarity.

\section{Cointegration Test}

Most macroeconomics/finance theories or postulates are based on equilibrium framework. Thus, the need of a cointegration test is vital to aid establish long-run bound among series. The traditional cointegration test (see Johansen, 1991;Johansen \& Juselius, 1990) fail to account for structural break(s). Thus, new breeds of cointegration test are available in the econometrics literature that help circumvent for spurious analysis and help account for the breaks (Gregory \& Hansen, 1996; Westerlund \& Edgerton, 2007). The mentioned test interestingly accounts for single structural break. Given the nature of the macroeconomic variable it is arguable that such estimators are flawed. Thus, this study employs Maki (2012) ${ }^{3}$ cointegration test, which accounts for multiple structural breaks. The equations for Maki (2012) are given as:

Model I: Break in intercept and without trend

$$
z_{t}=\mu+\sum_{i=1}^{m} \mu_{i} D_{i, t}+\delta^{\prime} x_{t}+u_{t}
$$

Model II: Break in intercept and coefficients and without trend

\footnotetext{
${ }^{3}$ The authors are grateful to Prof. Daiki Maki of the Faculty of Economics, Ryukoku University for the availability of the codes in GAUSS that facilitated simulation of the cointegration results
} 
Festus Victor Bekun, Mary Oluwatoyin Agboola. Electricity Consumption and Economic Growth Nexus: Evidence from ...

$$
z_{t}=\mu+\sum_{i=1}^{m} \mu_{i} D_{i, t}+\delta^{\prime} x_{t}+\sum_{i=1}^{m} \delta_{i}^{\prime} x_{t} D_{i, t}+u_{t}
$$

Model III: Break only in intercept and coefficients, but model has trend

$$
z_{t}=\mu+\sum_{i=1}^{m} \mu_{i} D_{i, t}+\beta t+\delta^{\prime} x_{t}+\sum_{i=1}^{m} \delta_{i}^{\prime} x_{t} D_{i, t}+u_{t}
$$

Model IV: Break in intercept, coefficients and trend

$$
\begin{aligned}
& z_{t}=\mu+\sum_{i=1}^{m} \mu_{i} D_{i, t}+\beta t+\sum_{i=1}^{m} \beta_{i} t D_{i, t}+ \\
& \delta^{\prime} x_{t}+\sum_{i=1}^{m} \delta_{i}^{\prime} x_{t} D_{i, t}+u_{t}
\end{aligned}
$$

Here, the $D_{i}$ is a dummy, where $D_{i=1}$ when $t>T_{b}$ and $\mathrm{D}_{\mathrm{i}}=0$, where $\mathrm{T}_{\mathrm{b}}$ indicates possible break point.

\section{Estimation of Long-Run Coefficients}

Long-run equilibrium coefficients become necessary after the establishment of cointegration relationship among the variables under review. To this end, dynamic ordinary least squares (DOLS) and fully modified least squares (FMOLS) estimation tests are employed to determine the magnitude of long-run equilibrium. The merits of the DOLS include that the DOLS can be estimated regardless of the order of integration of series, but the dependent variable is expected to be integrated of order one. Also, DOLS helps to circumvent for serial correlation problem estimation of the model and other internalities (see Esteve \& Requena, 2006).

The formula for DOLS model is given as:

$$
\begin{aligned}
& \ln E L E=\beta_{0}+\beta_{1} \ln C O_{2, t}+\beta_{2} \ln P G D P_{t}+ \\
& \sum_{i=-q}^{q} \varphi_{i} \Delta \ln C O_{2, t-1}+\sum_{i=-q}^{q} \gamma_{i} \Delta \ln P G D P_{t-1}+\mu_{t}
\end{aligned}
$$

where q represents the optimum lag level as suggested by Schwarz Information Criterion.

\section{Causality Test}

Traditional causality does not connote causation. Thus, a causality relationship is essential given the inherent policy implication that can be gleaned from such analysis. This study adopts the Toda-Yamamoto (1995) causality technique for predictive power among variables. The Toda-Yamamoto causality test (TY hereafter) is a modified fashion of the Wald test (MWALD). The TY causality test has pertinent advantages over the conventional Granger causality test. TY causality is known to have more resilience. Furthermore, beyond being resilient, TY approach is peculiar in the sense that it can be estimated regardless of the order of integration of variables considered. The technique is structured in a Vector Autoregressive framework VAR with $\left(\mathrm{K}+\mathrm{d}_{\max }\right)$ where, $\mathrm{K}$ is the optimal order of integration in the VAR and $d_{\max }$ is the maximum integration order.

The $\operatorname{VAR}\left(\mathrm{K}+\mathrm{d}_{\max }\right)$ is given as:

$$
\begin{aligned}
& \ln E L E=\beta_{0}+\sum_{i=1}^{m} \beta_{1 i} \ln E L E_{t-i}+\sum_{j=k+1}^{d_{\max }} \beta_{1 j} \ln E L E_{t-j}+\sum_{i=1}^{m} \alpha_{1 i} \ln C O_{2, t-i}+ \\
& d_{\sum_{j=k+1} \alpha_{2 j} \ln C O_{2, t-j}+\sum_{i=1}^{m} \delta_{1 i} \ln P G D P_{t-i}+d_{j=k+1} \delta_{\max }} \delta_{2 j} \ln P G D P_{t-j}+\varepsilon_{1 t}
\end{aligned}
$$$$
\ln C O_{2}=\alpha_{0}+\sum_{i=1}^{m} \alpha_{1 i} \ln C O_{2, t-i}+\sum_{j=k+1}^{d_{\max }} \alpha_{2 j} \ln C O_{2, t-j}+\sum_{i=1}^{m} \beta_{1 i} \ln E C_{t-i}+
$$$$
\sum_{j=k+1}^{d_{\max }} \beta_{2 j} \ln E L E_{t-j}+\sum_{i=1}^{m} \delta_{1 i} \ln P G D P_{t-i}+\sum_{j=k+1}^{d_{\max }} \delta_{2 j} \ln P G D P_{t-j}+\varepsilon_{2 t}
$$

$$
\begin{aligned}
& \ln P G D P=\delta_{0}+\sum_{i=1}^{m} \delta_{1 i} \ln P G D P_{t-i}+\sum_{j=k+1}^{d_{\max }} \delta_{2 j} \ln P G D P_{t-j}+\sum_{i=1}^{m} \alpha_{1 i} \ln C O_{2, t-i}+ \\
& d_{\max } \alpha_{2 j} \ln C O_{2, t-j}+\sum_{i=1}^{m} \beta_{1 i} \ln E L E_{t-i}+d_{j=k+1} \beta_{\max } \beta_{2 j} \ln E L E_{t-j}+\varepsilon_{3 t}
\end{aligned}
$$

\section{Empirical Results/Discussions}

This section provides the empirical estimations and results. Figure 1 provides the visual plots of the series which conspicuously shows points of possible breaks. The break years reflect political and economic episodes in the country under investigation. Thus, this study uses estimators that account for such breaks in order to avoid spurious analysis.

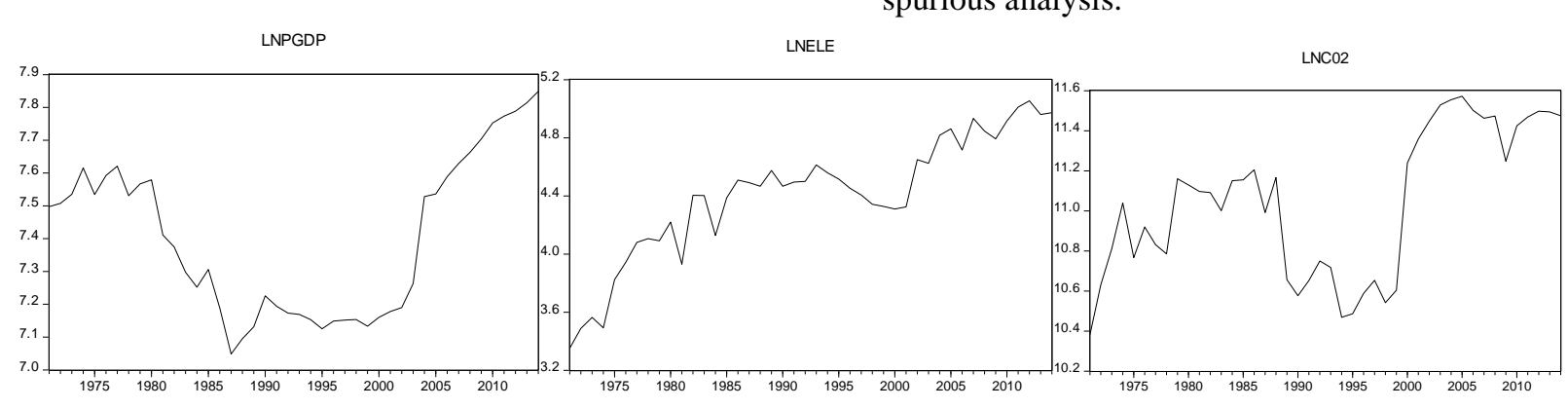

Figure 1. Visual Plots of Series under Review 
ZA (1992), Tests for Unit Root under a Single Structural Break

\begin{tabular}{|c|c|c|c|c|c|c|c|}
\hline & \multicolumn{3}{|c|}{ Statistics (Level) } & \multicolumn{3}{|c|}{ Statistics (First Difference) } & \multirow[b]{2}{*}{ Conclusion } \\
\hline & $\mathbf{Z A}_{\mathbf{I}}$ & $\mathbf{Z A}_{\mathbf{T}}$ & $\mathbf{Z A}_{\mathbf{B}}$ & $\mathbf{Z A}_{\mathbf{I}}$ & $\mathbf{Z A}_{\mathbf{T}}$ & $\mathbf{Z A}_{\mathbf{B}}$ & \\
\hline $\ln \mathrm{ELE}$ & -3.68 & -4.13 & -3.28 & $-8.33 *$ & $-6.62^{*}$ & $-8.58 *$ & $\mathrm{I}(1)$ \\
\hline Time Break & 1995 & 1995 & 1995 & 2002 & 1997 & 2002 & \\
\hline Lag Length & 1 & 0 & 1 & 1 & 1 & 1 & \\
\hline $\ln \mathrm{CO}_{2}$ & -5.51 & -3.21 & -5.15 & $-7.63^{*}$ & $-6.98^{*}$ & $-8.12 *$ & $\mathrm{I}(1)$ \\
\hline Time Break & 2000 & 1995 & 2000 & 1996 & 1988 & 2000 & \\
\hline Lag Length & 1 & 1 & 1 & 1 & 1 & 1 & \\
\hline $\ln P G D P$ & -2.92 & -3.30 & -3.13 & $-7.34 *$ & $-7.35^{*}$ & $-7.46^{*}$ & $\mathrm{I}(1)$ \\
\hline Time Break & 2004 & 1995 & 1994 & 1978 & 1982 & 1988 & \\
\hline Lag Length & 1 & 1 & 1 & 1 & 1 & 1 & \\
\hline
\end{tabular}

Note: Ln ELE is electricity consumption, $\mathrm{CO}_{2}$ is carbon dioxide emissions and PGDP is real gross domestic product per capita. All of the variables are at their natural logarithms. $Z A_{I}$ represents the model with a break in the intercept; $Z A_{T}$ is the model with a break in trend; $Z A_{B}$ is the model with a break in both the trend and intercept. * indicates significance at the 1 per cent level.

Table 1 above reports the Zivot-Andrews (1992) unit root test suggesting that all the data series are nonstationary at level form. However, after first differencing all series under review became stationary when a single break was allowed. Thus, all series are integrated of same order $\sim \mathrm{I}(1)$. Results in Table 1 prompt the need for a structural break cointegration test such as the Maki cointegration test as the most appropriate for long-run equilibrium relationship with null hypothesis of no cointegration against an alternative of cointegration. The cointegration test is presented in Table 2. The result depicts the existence of a long-run equilibrium relationship between electricity consumption, $\mathrm{CO}_{2}$ emissions and real gross domestic product per capita under multiple structural breaks. The cointegration test under multiple structural breaks, as reported by Maki cointegration, shows several break years. This break year reflects both political and financial instability episodes experienced in Nigeria. Among such is in year 1999, as reported in our Maki result. Nigeria had its first democratic government rule and this had its implication on the energy sector. Similarly, 2007 also birthed another political regime. However, Nigeria's electricity power development is dated to the 1950s with the Electricity Corporation of Nigeria (ECN) while 1973 saw the birth of Nigeria Electric Power Authority (NEPA), a merger between ECN and Niger Dam Authority.

Several reforms were enacted to salvage the country's epileptic electricity supply and general energy sector, especially in the late 2000s; during this period, NEPA became a public limited company and the name was once again transformed to the Power Holding Company of Nigeria (PHCN). In 2013, the wave of privatisation also had its toll on the energy sector with the privatisation of PHCN and transformation to the Nigeria Electricity Regulatory Commission (NERC) which was saddled with the mandate of generation and distribution of energy. All the above data are captured in Table 2 in regards the implications. Similarly, financial instability, such as the global financial crisis years, 2006-2009, was seen in the break years. There is a strong correlation between financial stability and economic growth. This assertion is validated by conventional wisdom and empirical intuitions.
Furthermore, this study investigates the effect of privatisation of the electricity sector on economic growth. By conducting a restricted regression before and after the privatisation episodes, the partial effect of per capita GDP and $\mathrm{CO}_{2}$ on electricity consumption are evident. Table 3 presents the restricted regression. The study reveals a positive and significant impact of privatisation on electricity consumption, as seen in Table 3 . Although prior to privatization has a positive effect as well as after on electricity consumption. Interestingly, our study shows that carbon dioxide emission is less in effect before privatization relative to after privatization. This is revealing and indicative to environmental economists. This implies that private venture installations are not environmental friendly. Thus, adequate sanctions should be applied by government authorities to switch to more environmentally friendly plants and installations.

Strikingly and unexpectedly our study found less impact of per capita GDP after privatization relative to before privatization on electricity consumption in Nigeria. The possible explanation for this phenomenon could be the newly introduced prepaid meters for energy consumers. Thus, implying regulation on the demand side for energy (electricity) consumption. Although over the years, Nigeria power sector has suffered challenges that impede optimal delivery of power to her citizens. The country is known to have failed in her vision 20:2020 and her renewable energy master plan as well as the joint efforts of energy commission of Nigeria and the united nation development program. The plausible answer to these is captured in the studies of (Ajayi \& Ajayi, 2013), were poor willpower from the government, lack of incentives and multiple taxations as well as unfavorable custom duties crowded out investors to her energy sector and the realization of her renewable energy dreams. Poor and weak legal laws to aid the quest was also highlighted. This is a wake-up call for the government to be more committed to her energy commitment for national development. 
Festus Victor Bekun, Mary Oluwatoyin Agboola. Electricity Consumption and Economic Growth Nexus: Evidence from ...

Model: $E L E=f(P G D P, C 02)^{4}$

Table 2

Maki Cointegration Test under Multiple Structural Breaks

\begin{tabular}{cccc}
\hline Number of Break & $\begin{array}{c}\text { Test } \\
\text { Statistics }\end{array}$ & Break Points \\
\hline Points & & [Critical Values] & \\
\hline $\mathrm{TB} \leq 5$ & & & \\
& & & \\
& Model 0 & $-7.18[-5.76]^{*}$ & $1987 ; 1989 ; 1999 ; 2003 ; 2007$ \\
& Model 1 & $-7.51[-5.99]^{*}$ & $1973 ; 2003 ; 2008 ; 2010 ; 2012$ \\
& Model 2 & $-7.88[-7.28]^{*}$ & $1980 ; 1986 ; 1990 ; 2007 ; 2011$ \\
& Model 3 & $-8.53[-8.12]^{*}$ & $1978 ; 1988 ; 1995 ; 2001 ; 2006$ \\
\hline
\end{tabular}

Note: numbers in [ ] denotes critical values at 0.05 level obtained from Maki's (2012) generic article while

* signifies statistical significance at 0.01 significance level.

Table 3

Estimation Results Before and After Privatisation

\begin{tabular}{ccccc}
\hline Variables & Before privatisation & & $\begin{array}{c}\text { After } \\
\text { Privatization }\end{array}$ & FMOLS \\
\hline LnPGDP & DOLS & FMOLS & DOLS & $0.765(0.000)^{* * *}$ \\
LnCO2 & $1.142(0.000)^{* * *}$ & $1.677(0.000)^{* * *}$ & $0.658(0.009)^{* * *}$ & $0.715(0.000)^{* * *}$ \\
\hline
\end{tabular}

Note: ( ) are P-value.

Table 4

Cointegration Coefficients

\begin{tabular}{lll}
\hline Variables & DOLS & FMOLS \\
\hline LnPGDP & $0.198(0.084)^{*}$ & $0.699(0.019)^{* *}$ \\
LnC02 & $0.467(0.215)$ & $0.085(0.417)$ \\
\hline
\end{tabular}

Note: $* * * * * *$ denote rejection at $0.01,0.05$ and 0.1 significance level respectively. while numbers in () are $P$-value.

Furthermore, this study proceeds to investigate the magnitude of the cointegration via dynamic ordinary least square (DOLS) and fully modified ordinary least square (FMOLS) regression for the full sampled period. Table 4 shows that both per capita GDP and $\mathrm{CO}_{2}$ contribute positively and exert an inelastic effect on electricity consumption. GDP per capita contributes significantly positively to electricity consumption in Nigeria. That is, a $1 \%$ increase in economic activities birth a corresponding $0.19 \%$ and $0.69 \%$ for DOLS and FMOLS respectively increase in electricity consumption. However, carbon dioxide emissions contributes positively though not significant. This implies that the nation emission is yet to reach the intolerable threshold. This is indicative to energy and environmentalist that formulate and design energy regulations/laws. This is necessary given the global awareness toward cleaner and renewable energy sources. This position is strengthen in the studies of (inter alia Shahbaz et al., 2012; Balsalobre et al., 2018). Our study position corroborates the finding of (Akinwale et al., 2013; Agbaje \& Idachaba, 2018) for the case of Nigeria.
Subsequently, this study proceeds to account for the directional causality among series through the TodaYamamoto (1995) causality test. Table 5 provides the TY causality results. There exists unidirectional causality running from electricity consumption to carbon dioxide emissions. Also seen is unidirectional causality running from electricity consumption to economic growth, which is very insightful in the study area. Thus, this study validates the electricity-led growth hypothesis for the case of Nigeria. Thus, affirming that the Nigerian economy is energy (electricity)-dependent. Our findings corroborates with findings of Shahbaz et al., (2017) for Portuguese economy. Thus, the revelation of the Nigerian economy being electricity-dependent implies that a conservative policy would have negative effect on its economic growth. That is, caution should be taken while designing energy policy and implementation. However, no causal interaction is observed running from carbon dioxide emissions and per capita GDP, or vice versa, for this study.

\footnotetext{
${ }^{4}$ As suggested in Maki's (2012) generic paper, four models were provided: (1) breaks at level shift; (2) level shift with trend; (3) regime shift; (4) trend and regime shift. This study reports model 4 with trend and regime shift for the brevity of space as other models are in harmony of cointegration relationship among the investigated series. The rest can be made available upon request.
} 
Festus Victor Bekun, Mary Oluwatoyin Agboola. Electricity Consumption and Economic Growth Nexus: Evidence from ...

Table 5

Toda-Yamamoto (1995) causality test

\begin{tabular}{lcc}
\hline \multicolumn{1}{c}{ Hypothesis } & Chi-square P-value & Decision \\
\hline $\ln E L E C$ does not cause $\ln C \mathrm{O}_{2}$ & $0.01^{* *}$ & Reject \\
$\ln C \mathrm{O}_{2}$ does not cause $\ln E L E$ & 0.28 & Fail to Reject \\
$\ln P G D P$ does not cause $\ln E L E$ & 0.02 & Fail Reject \\
$\ln E L E$ does not cause $\ln P G D P$ & $0.38^{* *}$ & Reject \\
$\ln C \mathrm{O}_{2}$ does not cause $\ln P G D P$ & 0.79 & Fail to Reject \\
$\ln P G D P$ does not cause $\ln C \mathrm{O}_{2}$ & 0.13 & Fail to Reject \\
\hline
\end{tabular}

Note: **indicates 5 per cent significance level.

\section{Residual Diagnostic Test}

The result of the residual diagnostic test is presented in Table 6.

Residual Diagnostic Test

\begin{tabular}{|c|c|c|c|}
\hline \multicolumn{4}{|c|}{ Normality } \\
\hline Jarque- Bera & 2.646712 & & $(0.266)$ \\
\hline \multicolumn{4}{|c|}{ Breusch-Godfrey Serial Correlation LM Test } \\
\hline F-stat & 1.901 & Prob. F(2, 29) & $(0.129)$ \\
\hline \multicolumn{4}{|c|}{ White Heteroscedasticity Test: White } \\
\hline F-stat & 1.809 & Prob. F(2,38) & $(0.134)$ \\
\hline
\end{tabular}

Note: () are probabilities numbers

Table 6 presents the diagnostic test for this study; from the above estimates, the model selected for this study is normally distributed, as reported by the Jarque Brea Normality test, and this study model is also free from serial correlation and heteroscedasticity. The CUSUM and

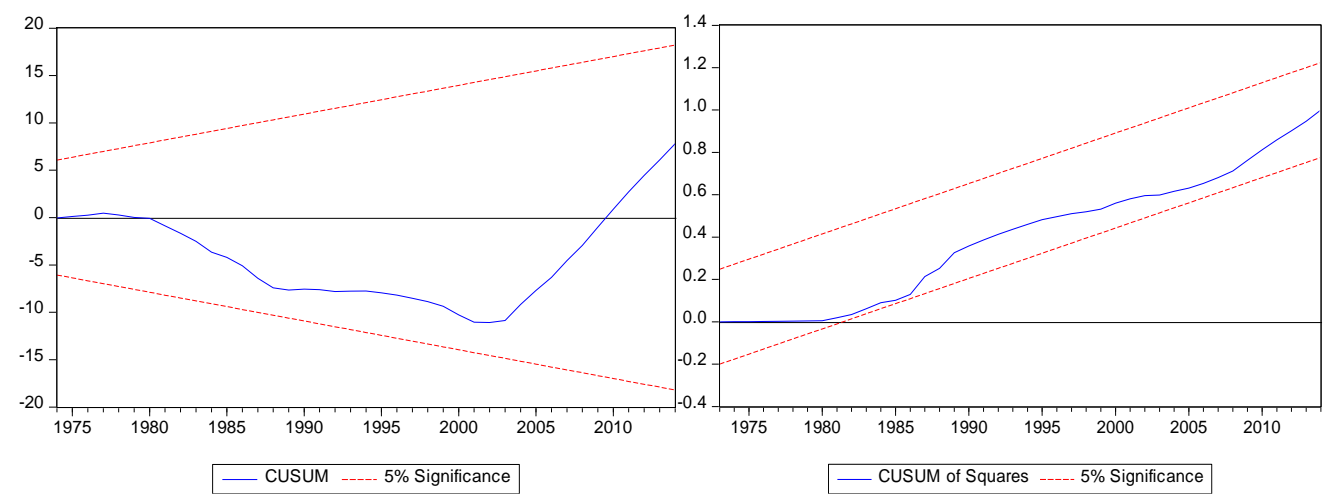

Figure 2 and 3. Renders the CUSUM and CUSUM for Model Stability

\section{Concluding Remarks/Policy Implications}

This country-specific study validates the electricityinduced growth for the case of Nigeria using annual data from 1971-2014. Data were retrieved from the WDI CDROM (2018). This study is conducted in a trivariate framework as against previous studies conducted in a bivariate frame work. This study's novelty lies in methodological innovation and by scope with the inclusion of $\mathrm{CO}_{2}$ in the econometrics framework. The unit root test according to Zivot-Andrews (1992) unit root test under single structural break depicts that all series are stationary after first difference, while, for equilibrium relationship, Maki (2012) is adopted for cointegration relationship and,
CUSUMsq plots were found between the $95 \%$ confidence interval, thus, confirms the stability of the fitted model. This indicates that the model for this study is fit and robust for model policy direction in Nigeria.

Table 6 
the electricity-induced carbon dioxide emissions resonates with the findings of Itodo et al. (2017). Furthermore, unidirectional causality is seen running from electricity consumption to $\mathrm{CO}_{2}$ emissions, which implies a tradeoff between industrialisation and electricity consumption in Nigeria.

In summary, the findings of this study and possible implications are:

There is need for policy makers in Nigeria to raise economic activity by enhancing electricity consumption as a stimulus for economic growth. This can be achieved via the following routes, namely, (a) effective electricity generation and distribution to all areas and (b) optimum electricity tariff to induce more electricity consumption; however, this action can crowd out investors and investment in the energy sector, so an optimal tariff is encouraged.
Also, a unidirectional causality from electricity consumption to $\mathrm{CO}_{2}$ calls for the attention of policy makers and environmental specialists to design environmentally friendly strategies like the Kyoto-Protocol agreement, which Nigeria is not yet part of.

In conclusion, the need for policy makers to diversify the energy portfolio to other sources of energy that are environmentally friendly, such as photovoltaic energy, biofuel and wind energy, is crucial at a time where the entire globe is clamouring for a clean society. This is further resonated in the studies of Ajayi and Ajanaku (2009) of the laudable role energy especially renewable energy availability, its supply, demand and use play as a key determinant of national development. Thus, policy makers are encouraged to take pragmatic strides to the energy sector rather than mere lip service, if the full gains are to be gleaned from the energy sectors as seen in other economies.

\section{References}

Ajayi, O. O., \& Ajayi, O. O. (2013). Nigeria's energy policy: Inferences, analysis and legal ethics toward RE development. Energy Policy, 60, 61-67. https://doi.org/10.1016/j.enpol.2013.05.095

Ajayi, O. O., \& Ajanaku, K. O. (2009). Nigeria's energy challenge and power development: the way forward. Energy \& environment, 20(3), 411-413. https://doi.org/10.1260/095830509788066448

Agbaje, B. A., \& Idachaba, E. (2018). Electricity Consumption, Corruption and Economic Growth: Evidence on Selected African Countries. International Journal for Innovation Education and Research, 6(4), 193-214.

Akadiri, S. S. \& Akadiri, A. C. (2018). Interaction between CO2 emissions, energy consumption and economic growth in the Middle East: Panel causality evidence. International Journal of Energy Technology and Policy (in press).

Akadiri, S. S., Bekun, V. F., Taheri, E., \& Akadiri, A. C. (2018). Carbon emissions, energy consumption and economic growth: A causality evidence. International Journal of Energy Technology and Policy (in press).

Akinwale, Y., Jesuleye, O., \& Siyanbola, W. (2013). Empirical analysis of the causal relationship between electricity consumption and economic growth in Nigeria. British Journal of Economics, Management and Trade, 3(3), 277295. https://doi.org/10.9734/BJEMT/2013/4423

Ameyaw, B., Oppong, A., Abruquah, L. A., \& Ashalley, E. (2016). Causality nexus of electricity consumption and economic growth: an empirical evidence from Ghana. Open Journal of Business and Management, 5(01), 1-10. https://doi.org/10.4236/ojbm.2017.51001

Aslan, A. (2014). Causality between electricity consumption and economic growth in Turkey: An ARDL bounds testing approach. Energy Sources, Part B: Economics, Planning, and Policy, 9(1), 25-31. https://doi.org/10.1080/ 15567241003681882

Balcilar, M., Ozdemir, Z. A., \& Arslanturk, Y. (2010). Economic growth and energy consumption causal nexus viewed through a bootstrap rolling window. Energy Economics, 32, 1398-1410. https://doi.org/10.1016/j.eneco.2010.05.015

Balsalobre-Lorente, D., M. Shahbaz, Roubaud, D., \& Farhani. S. (2018). How economic growth, renewable electricity and natural resources contribute to CO 2 emissions? Energy Policy 113, 356-367. https://doi.org/10.1016/j. enpol.2017.10.050

Baranzini, A., Weber, S., Bareit, M., \& Mathys, N. A. (2013). The causal relationship between energy use and economic growthin Switzerland. Energy Economics, 36, 464-470. https://doi.org/10.1016/j.eneco.2012.09.015

Belaïd, F., \& Abderrahmani, F. (2013). Electricity consumption and economic growth in Algeria: A multivariate causality analysis in the presence of structural change. Energy Policy, 55, 286-295. https://doi.org/10.1016/j. enpol.2012.12.004

Central Intelligence Agency World Fact Book (CIA-WFB). 2018. Asia. Pakistan Report. Washington,C:CentralIntelli genceAgencyavailablehttps://www.indexmundi.com/pakistan/electricity_access.html

Damette, O., \& Seghir, M. (2013).Energy as a driver of growth in oil exporting countries? Energy Economics, 37, 193199. https://doi.org/10.1016/j.eneco.2012.12.011

Dickey, D. A., \& Fuller, W. A. (1979). Distribution of the estimators for autoregressive time series with a unit root. Journal of the American statistical association, 74, 427-431. 
Dlamini, J., Balcilar, M., Gupta, R., \& Inglesi-Lotz, R. (2015).Revisiting the causality between electricity consumption and economic growth in South Africa: a bootstrap rolling-window approach. International Journal of Economic Policy in Emerging Economies, 8(2), 169-190. https://doi.org/10.1504/IJEPEE.2015.069595

Emir, F., \& Bekun, F. V. (2018). Energy intensity, carbon emissions, renewable energy, and economic growth nexus: New insights from Romania. Energy \& Environment, 1-17 doi.org/10.1177/0958305X18793108

Energy Information Administration (EIA). 2016. Nigeria: Country Analysis. Washington, DC: US Department of Energy: Energy Information Administration.

Esteve, V., \& Requena, F. (2006). A cointegration analysis of car advertising and sales data in the presence of structural change. International Journal of the Economics of Business, 13(1), 111-128. https://doi.org/10.1080/135715 10500520036

Gregory, A. W., \& Hansen, B. E. (1996). Residual-based tests for cointegration in models with regime shifts. Journal of Econometrics, 70, 99-126. https://doi.org/10.1016/0304-4076(69)41685-7

Halicioglu, F. (2009). An econometric study of CO2 emissions, energy consumption, income and foreign trade in Turkey. Energy Policy, 37, 1156-1164. https://doi.org/10.1016/j.enpol.2008.11.012

Hamdi, H., Sbia, R., \& Shahbaz, M. (2014). The nexus between electricity consumption and economic growth in Bahrain. Economic Modelling, 38, 227-237. https://doi.org/10.1016/j.econmod.2013.12.012

Itodo, I. A., Safaeimanesh, S., \& Bekun, F. V. (2017). Energy use and growth of manufacturing sector: evidence from Turkey. Academic Journal of Economic Studies, 3, 88-96.

Faisal, J., \& Ahmad, E. (2010). "The relationship between electricity consumption, electricity prices and GDP in Pakistan." Energy policy 38, 6016-6025. https://doi.org/10.1016/j.enpol.2010.05.057

Johansen, S. (1991). Estimation and hypothesis testing of cointegration vectors in Gaussian vector autoregressive models. Econometrica: Journal of the Econometric Society, 1551-1580. https://doi.org/10.2307/2938278

Johansen, S., \& Juselius, K. (1990).Maximum likelihood estimation and inference on cointegration-with applications to the demand for money. Oxford Bulletin of Economics and statistics, 52, 169-210. https://doi.org/10.1111/j.14680084.1990.mp52002003.x

Jumbe, C. B. (2004). Cointegration and causality between electricity consumption and GDP: empirical evidence from Malawi. Energy economics, 26(1), 61-68. https://doi.org/10.1016/S0140-9883(03)00058-6

Kahouli, B. (2018). The causality link between energy electricity consumption, CO2 emissions, R\&D stocks and economic growth in Mediterranean countries (MCs). Energy, 145, 388-399. https://doi.org/10.1016/j.energy.20 17.12 .136

Kayhan, S., Adiguzel, U., Bayat, T., \& Lebe, F. (2010). Causality Relationship Between Real Gdp And Electricity Consumption in Romania. Romanian Journal of Economic Forecasting, 169-183.

Kraft, J., \& Kraft, A. (1978). "On the relationship between energy and GNP." Journal of Energy Development 3, $401-403$.

Lee, C. C., Chang, C. P., \& Chen, P. F. (2008). Energy-income causality in OECD countries revisited: The key role of capital stock. Energy Economics, 30, 2359-2373. https://doi.org/10.1016/j.eneco.2008.01.005

Maki, D. (2012). Tests for cointegration allowing for an unknown number of breaks. Economic Modelling, 29, 20112015. https://doi.org/10.1016/j.econmod.2012.04.022

Narayan, P. K., \& Smyth, R. (2008). Energy consumption and real GDP in G7 countries: new evidence from panel cointegration with structural breaks. Energy Economics, 30, 2331-2341. https://doi.org/10.1016/j.eneco.2007.10.006

Nazlioglu, S., Kayhan, S., \& Adiguzel, U. (2014). Electricity consumption and economic growth in Turkey: Cointegration, linear and nonlinear Granger causality. Energy Sources, Part B: Economics, Planning, and Policy, 9(4), 315-324. https://doi.org/10.1080/15567249.2010.495970

Nigerian Energy Support Programme (NESP). 2015. The Nigerian Energy Sector: An Overview with a Special Emphasis on Renewable Energy, Energy Efficiency and Rural Electrification. Eschborn, Germany: Deutsche Gesellschaft fur Internationale Zusammenarbeit (GIZ)

Payne, J. E. (2010). A survey of the electricity consumption-growth literature. Applied energy, 87, $723-731$. https://doi.org/10.1016/j.apenergy.2009.06.034

Phillips, P. C., \& Perron, P. (1988).Testing for a unit root in time series regression. Biometrika, 75, 335-346. https://doi.org/10.1093/biomet/75.2.335

Salahuddin, M., Gow, J., \& Ozturk, I. (2015). Is the long-run relationship between economic growth, electricity consumption, carbon dioxide emissions and financial development in Gulf Cooperation Council Countries robust?. Renewable and Sustainable Energy Reviews, 51, 317-326. https://doi.org/10.1016/j.rser.2015.06.005

Sekantsi, L. P., \& Okot, N. (2016).Electricity consumption-economic growth nexus in Uganda. Energy Sources, Part B: Economics, Planning, and Policy, 11, 1144-1149. https://doi.org/10.1080/15567249.2015.1010022 
Festus Victor Bekun, Mary Oluwatoyin Agboola. Electricity Consumption and Economic Growth Nexus: Evidence from ...

Sekantsi, L. P., Thamae, R. I., \& Mohatonyane, L. E. (2016). Electricity Consumption in Lesotho: The Role of Financial Development, Industrialisation and Urbanisation. Journal of International Business and Economics, 4(1), 1-12. https://doi.org/10.15640/jibe.v4n1a2

Shahbaz, M., \& Feridun, M. (2012). Electricity consumption and economic growth empirical evidence from Pakistan. Quality\& Quantity, 46, 1583-1599. https://doi.org/10.1007/s11135-011-9468-3

Shahbaz, M., Benkraiem, R., Miloudi, A., \& Lahiani, A. (2017). Production function with electricity consumption and policy implications in Portugal. Energy Policy, 110, 588-599. https://doi.org/10.1016/j.enpol.2017.08.056

Shahbaz, M., Zeshan, M., \& Afza, T. (2012). Is energy consumption effective to spur economic growth in Pakistan? New evidence from bounds test to level relationships and Granger causality tests. Economic Modelling 29 (6), $2310-$ 2319. https://doi.org/10.1016/j.econmod.2012.06.027

Soytas, U., \& Sari, R. (2006).Energy consumption and income in G-7 countries. Journal of Policy Modeling, 28, 739-750. https://doi.org/10.1016/j.jpolmod.2006.02.003

Tamba, J. G., Nsouandele, J. L., Fopah Lele, A., \& Sapnken, F. E. (2017). Electricity consumption and economic growth: Evidence from Cameroon. Energy Sources, Part B: Economics, Planning, and Policy, 12, $1007-1014$. https://doi.org/10.1080/15567249.2017.1349211

Tang, C. F., \& Tan, E. C. (2013).Exploring the nexus of electricity consumption, economic growth, energy prices and technology innovation in Malaysia. Applied Energy, 104, 297-305. https://doi.org/10.1016/j.apenergy.2012.10.061

Toda, H. Y., \& Yamamoto, T. (1995). Statistical inference in vector autoregressions with possibly integrated processes. Journal of Econometrics, 66, 225-250. https://doi.org/10.1016/0304-4076(94)01616-8

Wada, I. (2017a). Energy production and economic growth in Saudi Arabia: Dynamic causality. Energy Sources, Part B: Economics, Planning, and Policy, 12, 584-590. https://doi.org/10.1080/15567249.2016.1248872

Wada, I. (2017b). Dynamic causality in energy production and output growth in Nigeria revisited: ARDL bounds test approach. Energy Sources, Part B: Economics, Planning, and Policy, 12, 945-951. https://doi.org/10.10 $80 / 15567249.2017 .1327995$

Wang, J., Zhao, J., \& Li, H. (2017). The Electricity Consumption and Economic Growth Nexus in China: A Bootstrap Seemingly Unrelated Regression Estimator Approach. Computational Economics, 1-17.

Westerlund, J., \& Edgerton, D. L. (2007).New improved tests for cointegration with structural breaks. Journal of time series Analysis, 28, 188-224. https://doi.org/10.1111/j.1467-9892.2006.00504.X

Wolde-Rufael, Y. (2014). Electricity consumption and economic growth in transition countries: A revisit using bootstrap panel Granger causality analysis. Energy Economics, 44, 325-330. https://doi.org/10.1016/j.eneco.2014.04.019

World Bank Development Indicators (2018), Retrieved from http://databank.worldbank.org (January 2018).

Zivot, E., \& Andrews, D. W. K. (1992).Further evidence on the Great Crash, the oil price shock, and the unit root hypothesis. Journal of Business and Economic Statistics, 10(3), 251-270.

The article has been reviewed.

Received in May 2018; accepted in January 2019. 